\title{
The architecture of Early and Middle Neolithic settlements of the Starčevo culture in Northern Croatia
}

\author{
Kornelija Minichreiter \\ Institut of Archaeology, Zagreb, Croatia \\ kornelija.minichreiter@IARH.tel.hr
}

\begin{abstract}
In southeastern Europe, in the region of northern Croatia (between the Drava, Sava, and Danube Rivers), which geographically belongs to southern Pannonia, the first Neolithic settlements developed during the early and middle Neolithic, ca. 6000-4800 BC. Numerous archaeological excavations in the last 25 years have enabled an overview of the development of Starčevo Culture settlements (the earliest Neolithic culture in this region), from the first phases to the end of its development.

IZVLEČEK - V jugovzhodni Evropi na severnem Hrvaškem (med Dravo, Savo in Donavo), ki geografsko pripada južni Panoniji, so prve neolitske naselbine nastale v zgodnjem in srednjem neolitiku okoli 6000 do 4800 BC. Številna arheološka izkopavanja v zadnjih 25-ih letih nam omogočajo pregled razvoja naselbin kulture Starčevo (najzgodnej\{a neolitska kultura v regiji) od prvih faz do konca njenega razvoja.
\end{abstract}

KEY WORDS - southeastern Europe; southern Pannonia; Croatia; early and middle Neolithic; Starčevo Culture; settlements; architecture

\section{INTRODUCTION}

The first agricultural and pottery-using cultures developed during the early and middle Neolithic in the southeastern European region as parts of the common Starčevo Cultural complex, basically related in terms of material and spiritual culture, but nonetheless different in the cultural and territorial senses. The Starčevo Culture received its name from the village of Starčevo, on the left bank of the Danube, near Pančevo in Vojvodina (Yugoslavia), where the first major excavations were undertaken in 1931/ 1932. Settlements of the Starčevo Culture have been discovered in southern Hungary, northern Croatia, Vojvodina, Serbia proper, Kosovo, eastern Bosnia and northern Macedonia. The Starčevo cultural complex also includes the Körös Culture in eastern Hungary, the Cris Culture in Romania, the Čavdar-Kremikovci-Karanovo Culture in Bulgaria, and Anzabegovo-Vršnik in Macedonia. It extends throughout the early and middle Neolithic during the early Stone Age (Fig. 1).
In terms of its geographical position, Croatia is culturally oriented and attached to various regions. This was reflected as a major advantage in the luxuriant development of prehistoric cultures and their connections to the surrounding European regions. The region of northern Croatia was permanently integrated into the life and culture of the Pannonian plain and the southeastern Alpine region. Its northern and eastern part, Slavonia, Syrmia, and Baranja, is an area through which influences were spread from southeastern Europe and further from the region of Asia Minor, but also from the east, from the TransCaucasus and the Russian-Ukrainian steppe. Along with all these varied cultural connections, each of the cited Croatian regions was to retain its own autochthonous line of cultural development, ideas, and artistic expression.

To the present, 66 sites of the Starčevo Culture, belonging to the early and middle Neolithic, have been 


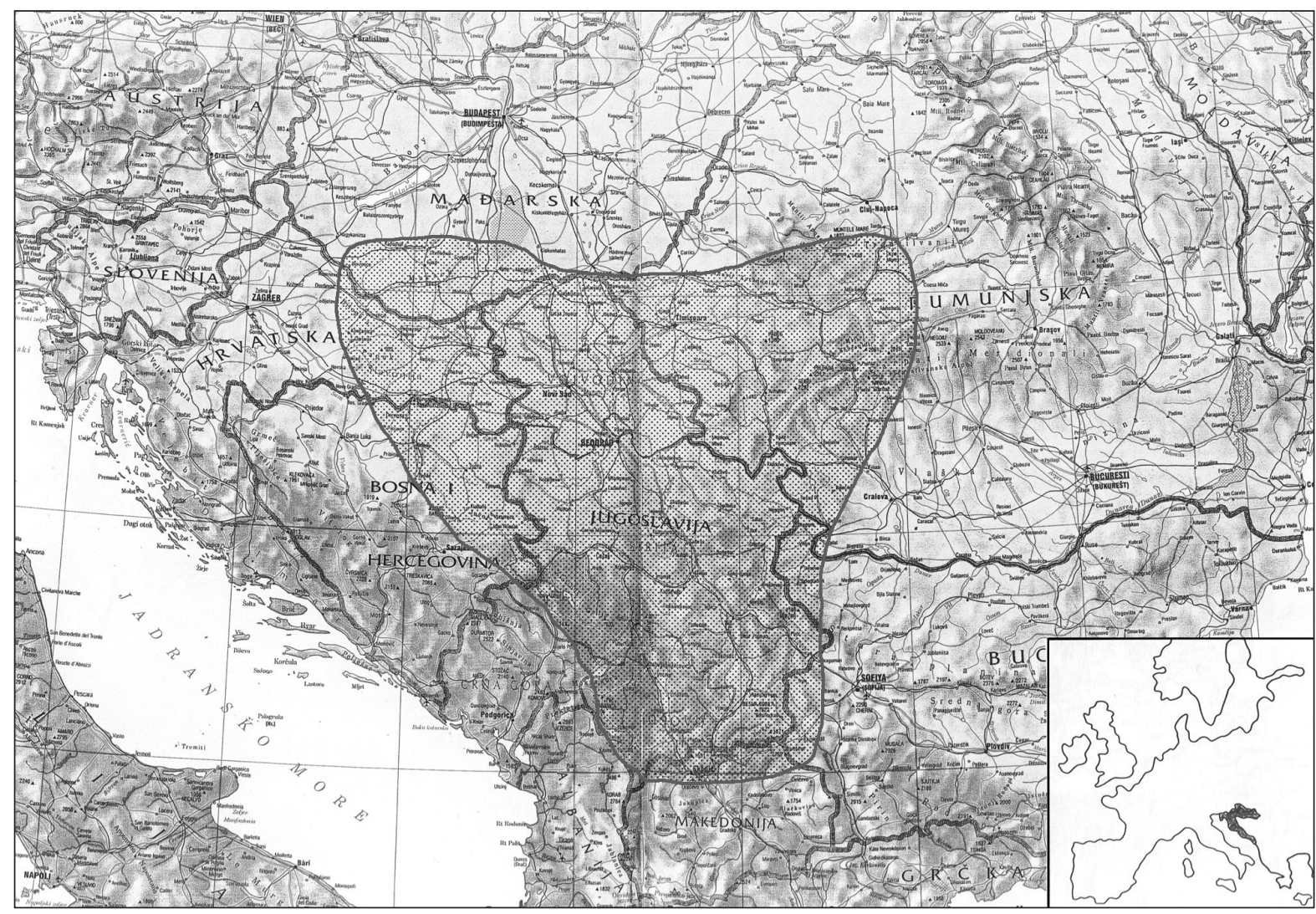

Fig. 1. Distribution map of Starčevo Culture in Southeast Europe.

documented in northern Croatia (Minichreiter 1997), and they are dated from the Linear A phase to the end of Spiraloid B (Fig. 2).

\section{THE CHRONOLOGICAL DIVISION OF THE STAR- ČEVO CULTURE}

The problems of a unified chronological system for the Starčevo Culture have still not been solved. The broad distribution and, primarily, single layered settlements, mean that 4 chronological systems are currently in use (Milojčić, Garašanin, Dimitrijević, and Srejović), each of which can be applied to a certain geographical region. Of the above authors, S. Dimitrijević was most involved with the Starčevo Culture and its relations to neighboring cultures (Dimitrijevic 1969; 1974; 1979), and he divided it (according to the stylistic traits of finds in southern Pannonia) into 7 phases: monochrome, Linear A, Linear B, Garlandoid, Spiraloid A, Spiraloid B, and a final phase.

Through a comparison of these four chronological systems, a division of the Starčevo Culture can be coordinated in the following manner (Fig. 3): the beginning developmental phases were named by the authors as Starčevo I (Milojčic 1950.109-111), Star- čevo I and IIa (Aranđelović-Garašanin 1954.131141), the Monochrome and Linear A phases (Dimitrijevic 1970.237-252), and Proto-Starčevo I and II (Srejović 1969.173-178).

The two beginning developmental phases were designated by S. Dimitrijević as the pre-classic Starčevo Culture, which differs from the classic developmental stages in that the vessels lack decoration with channeled barbotine. The decoration of coarse ware with channeled barbotine begins only in the following Linear B phase, denoting the beginning of the classic Starčevo Culture and the period of the middle Neolithic (Dimitrijevic 1979.242-243). The characteristics of the Linear A phase of the early Neolithic have been confirmed entirely by the numerous examples of pottery discovered in 1989-1990 in the rescue excavations of the Starčevo settlement at $\mathrm{Za}$ dubravlje (Minichreiter 1992.29, 37, 41-43), and the systematic excavations of the Starčevo settlement with a ritual-burial area at Slavonski Brod (Minichreiter 1998; 1999; 2000), which do not contain a single example of decoration with channeled barbotine. The painted motifs are linear, and the vessel shapes rounded, with no bi-conical forms. The classic developmental phase of the Starčevo Culture begins in the period of the middle Neolithic (the Linear 
$B$ according to $S$. Dimitrijević), with the widespread use of barbotine decoration on pottery vessels, which remains to the end of this culture, to the end of the Spiraloid B phase. The classic Starčevo Culture, in addition to linear painting, also contains painting of garlands (the Garlandoid phase), and in the final stages of Spiraloid A and B, spiral decorations also appear on the painted pottery.

Archaeological excavation in northern Croatia after 1985 has confirmed the chronological system of S. Dimitrijević for this region. Settlements of the Linear A stage were discovered at Zadubravlje and Slavonski Brod (Fig. 2), and 20 years earlier S. Dimitrijević had only hypothetically suggested the existence of a Linear A phase within his chronological division. A supplement and minor correction to the chronological system of S. Minichreiter was published in 1985, after the excavations at Pelana, whose archaeological material was placed by K. Minichreiter into a newly defined Linear $\mathrm{C}$ phase (Minichreiter 1990; 1992). Additionally, we consider that the other sites in western Slavonia (Stara Rača, Cernička Šagovina, and Ždralovi) can be placed in the Linear C stage, and not the final phase of the Starčevo Culture as defined by S. Dimitrijević.

\section{THE TOPOGRAPHICAL CHARACTERISTICS OF THE SETTLEMENTS - THE EARLIEST WATER-BA- SED ROUTES OF THE NEOLITHIC}

The topographical traits of the 66 documented settlements of the Starčevo Culture in northern Croatia indicate certain regularities in the choice of sites for settlements (Minichreiter 1997). The main conditions were the possibilities for sustenance: the cultivation of land, hunting areas, gathering fruits and nuts, and stock raising. Other fundamental conditions for life, because of which all Starčevo settlements were built along major or minor bodies of water, were drinkable water, irrigation, fishing, a large choice of river stones for making stone tools, and the possibility of trade connections along navigable routes. As a rule, one of three possibilities depending on terrain was chosen during the construction of a settlement along a water course:

- the high terraces along the banks of the Sava Drava, and Danube Rivers;

- low, sunny hills that gradually descend into small river valleys (for example, western Slavonia: a series of 5 settlements were discovered along with Pepelana in the Breznica River valley);

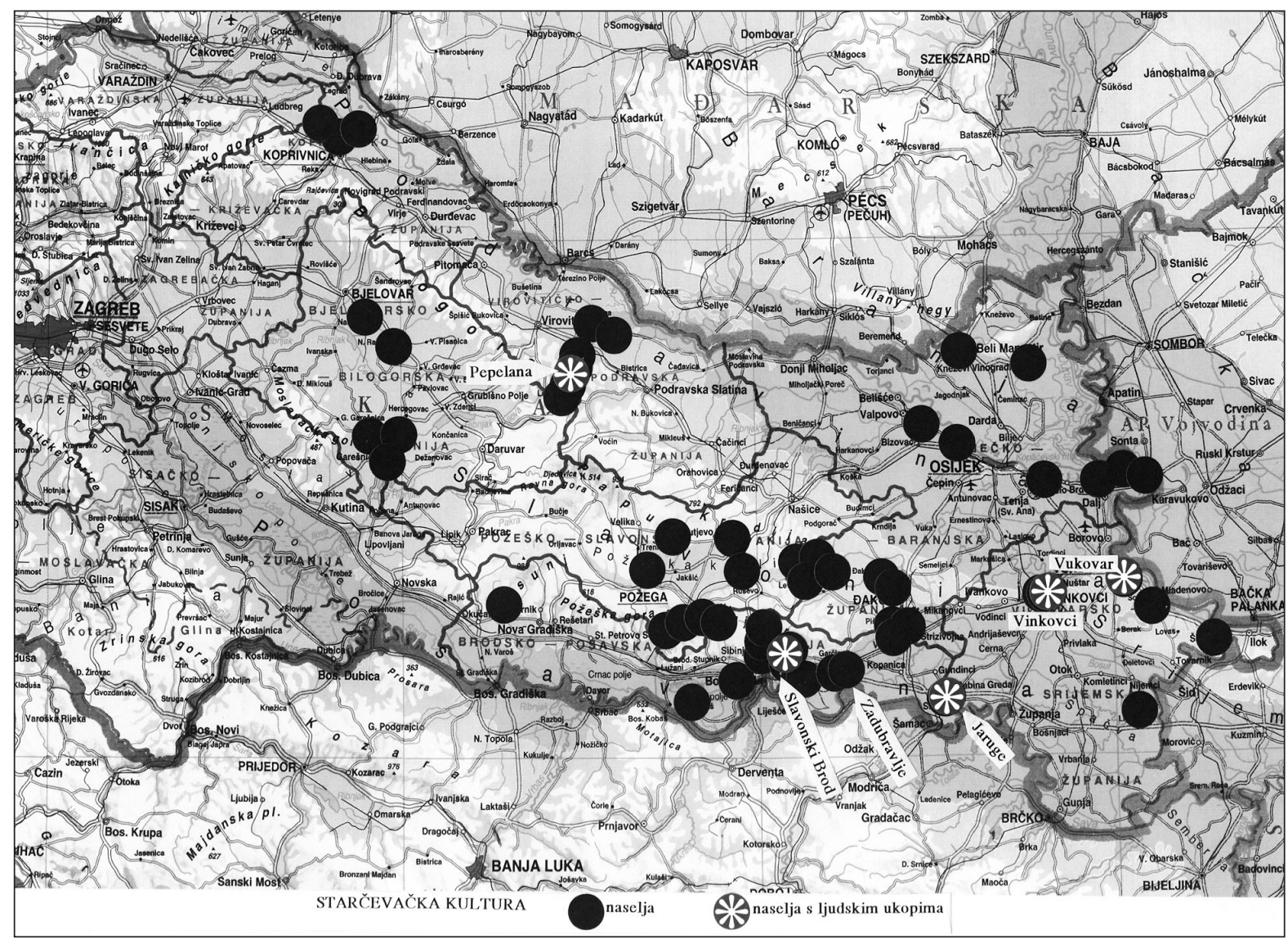

Fig. 2. Map of Starčevo sites in Northern Croatia. 
- gently raised, well-drained land; a crest or extension of a hill into a plain along former water courses.

The Starčevo settlements were never isolated and far from one another (a distance of 3-5 km), but were grouped in a row, in broads stream or river valleys, along water routes. More than half of the documented settlements were discovered in the past 10 years, and only now can they be mapped so as to enable the tracing of the earliest natural routes in northern Croatia. The wide rivers of the Danube, Sava, and Drava, characterized by their slow passage through plains, connected northern Croatia with the other Pannonian regions of this part of Europe. Their tributaries are equally important, which as the only possible natural routes, enabled the Neolithic population to penetrate deeply into the interior of the Slavonian highlands. The waters had a much greater volume of water during the Neolithic, and were navigable, while today, these are small rivers, streams, or even dry beds. The find of two canoes dated to the Neolithic (each made from a single piece of wood) in the Bid River, into which the Brezna Stream flows (running by the settlement at Zadubravlje), confirms the use of water courses for communication by the Neolithic inhabitants ( $M i$ nichreiter 1997a).

\section{THE ARCHITECTURE: TYPES OF PIT STRUCTURE IN STARČEVO CULTURE SETTLEMENTS}

The archaeological excavation of large surface areas of Starčevo Culture settlements at Vinkovci, Pepelana, Zadubravlje, and Slavonski Brod have enabled us to distinguish four basic types of pit structure ( $M i$ nichreiter 1992b; 1993): small pits (working pits or storage pits), medium sized structures (working pits with hearths or kilns, pit-dwellings with one or more rooms), and large pit-dwellings (residential and ritual-burial), and deep pits (wells).

- Small structures: working pits (pit-dwellings) or storage pits; circular, ellipsoid, or kidney-shaped in section, $2-3 \mathrm{~m}$ in diameter, $50-70 \mathrm{~cm}$ in depth, served as working pits, while pits of the same form, but dug deeper, $1-1.5 \mathrm{~m}$ ) were very probably storage pits.

At Zadubravlje, pits 19, 20, 21 (Fig. 4) were located in a workshop for producing stone tools. Pit 19 (an irregular rectangular form: $5 \times 3.5 \mathrm{~m}$, depth $50 \mathrm{~cm}$ ) contained around 2000 artifacts: microliths, cores, flakes, chips, whetstones, and unfinished tools, and it is presumed that this was a workshop for the production of stone tools. Pit 20 (an irregular circular form, $2 \times 2.5 \mathrm{~m}$, depth $20 \mathrm{~cm}$ ) and pit 21 (an elongated trefoil form, $3 \times 1.2 \mathrm{~m}$, depth $50 \mathrm{~cm}$ ), not far from pit 19 , were probably auxiliary working areas.

At Pepelana, pits 22 and 23 (Fig. 16, upper right corner) were shallow-dug into a plateau northeast of a large pit-dwelling. Given their kidney-shaped forms $(2.2 \times 1 \mathrm{~m}$, depth $40 \mathrm{~cm}$, and $1.5 \times .70$, depth 40 $\mathrm{cm})$, they could have served as working pits. Similar pits, only somewhat later in dating, were discovered at the Sopot Culture site of Gornji Brezovljani, cited by S. Dimitrijević as working areas (Dimitrijevic 1978.81-83, Fig. 16). Deep pits (Fig. 15) were dug into the edge sections of pit-dwellings, such as pit 10 (of ellipsoid form, $1.7 \times 0.90 \mathrm{~m}$, depth $1.2 \mathrm{~m}$ ), which served as storage and refuse pits.

At the "Cibalae Banka" site in Vinkovci, a group of pits (Fig. 18) were discovered (mostly circular, 3-5 $\mathrm{m}$ in diameter, depth $50-70 \mathrm{~cm}$ ), which most probably served as working areas (Iskra-Janošic 1984. 143).

- Medium sized structures (4-8 $\mathrm{m}$ in diameter with a base dug to $1 \mathrm{~m}$ in depth) were working pits with kilns (pottery workshops), and pit-dwellings with one or more rooms, with the rooms arranged according to purpose. The entrance in almost all pit-dwellings was over one or two steps on the eastern, sheltered side, as during the Neolithic period in these regions there were strong prevailing westerly winds (as a rule, drifts of loose prehistoric humus were found on the western side inside the pit-dwellings, indicating strong westerly winds). The edges of the pit-dwellings were formed into so-called "banks" or benches (Vinkovci), which served to support the roof structure, as seating, or for storing household items. The somewhat wider benches on the edges of the pitdwellings could also have been used for everyday tasks, and they probably also served for sleeping. 


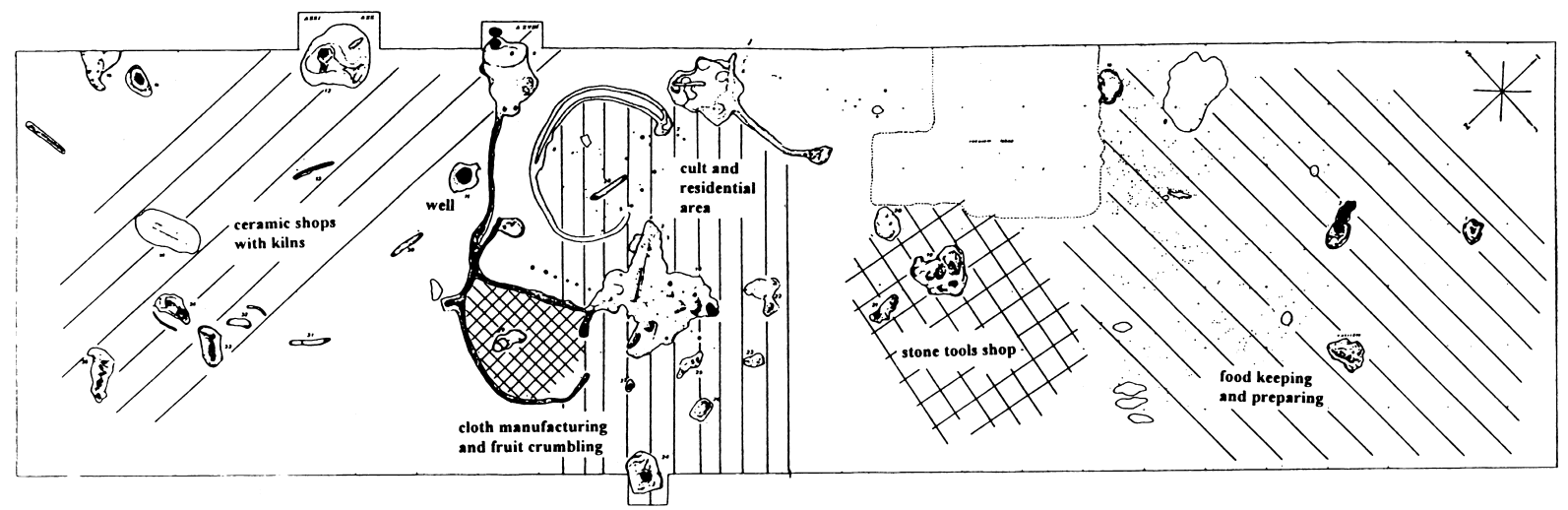

Fig. 4. Zadubravlje, plan of the Starčevo settlement.

Working pits with hearths, ovens, and kilns for various purposes (pits 9 and 12 with an oven for bread and a kiln for pottery) were discovered in the settlement at Zadubravlje (Minichreiter 1992c). In the western part of the settlement, where the pottery workshops were located, working pit 9 was built, in an ellipsoid form, $4.5 \times 6.5 \mathrm{~m}$, dug to a depth of ca. $60 \mathrm{~cm}$ from the surface of the settlement (Fig. 5). The base of the pit was almost flat over the entire area, and the sides were perpendicular except on the northeast, where there was a small entrance or access platform. A pothole from a perpendicular wooden beam $(30 \times 30 \mathrm{~cm}$, depth $10 \mathrm{~cm})$ was found in the northern part of the pit, probably serving as support for the roof structure. The pit was dug so that it had an undivided large working area in the central and northern area, while there were two ovens for baking bread (with hemispherical domes), and two (cylindrical) kilns for firing large pottery vessels in the southern part along the edge of the pit (Minichreiter 1992c.40-41). A shallow pit (50 cm x $60 \mathrm{~cm}$, depth $20 \mathrm{~cm}$ ) was dug into the floor in the northern part of the working pit, and opposite it, outside the working pit, was an identical small pit $(80 \times 70 \mathrm{~cm}$, depth $40 \mathrm{~cm})$. These small pits were probably used during the production process, or served for setting aside clay vessels. The western part of the working pit was full of a loose prehistoric humus that had accumulated because of the prevailing westerly winds, and a deposit of greasy gray ashy soil

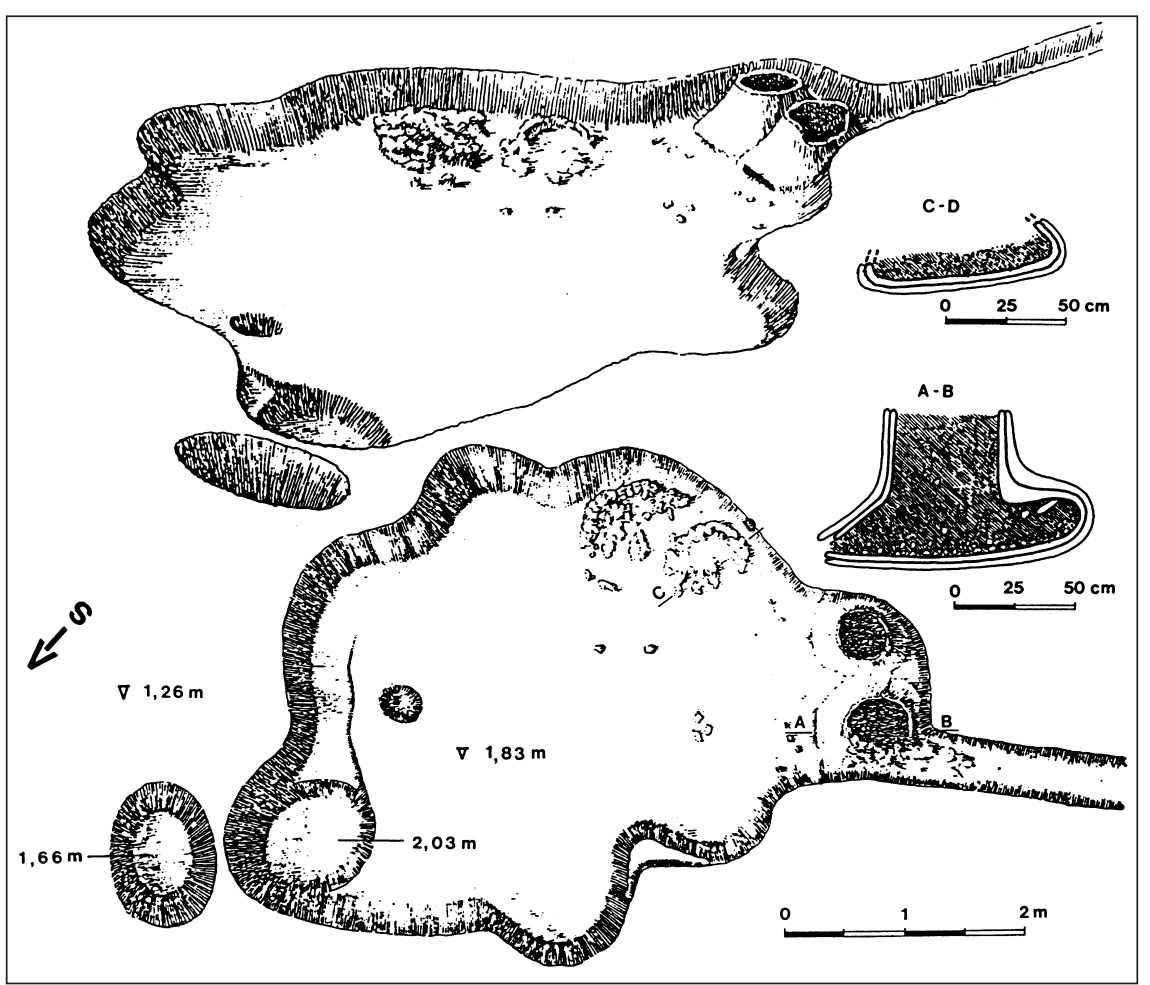

Fig. 5. Zadubravlje, working pit 9, pottery workshop with kilns, plan and perspective (drawing: Miljenko Gregl). was found in the northwestern section, probably remnants of ash from the ovens and kilns temporarily deposited here. The settlement also contained several small pits in which only ashes from the ovens and kilns were placed ( $M i$ nichreiter 1992.31, 32). Charcoal samples from the southwestern part of the working pit were dated by ${ }^{14} \mathrm{C}$ analysis to the period from 5720-5530 BC (6705 $\pm 95 \mathrm{BP})$.

To the west of working pit no. 9, another working pit (no. 12) was discovered, with kilns for firing pottery (Fig. 6). The working pit had an irregular circular shape, with dimensions of $5 \times 5.5 \mathrm{~m}$, with a 
dug out floor on two levels: the northern part was dug $30 \mathrm{~cm}$ from the edge of the pit, and the southern part was $30 \mathrm{~cm}$ deeper, i.e. $60 \mathrm{~cm}$ from the edge of the pit. The entrance to the working pit was probably on the eastern side in the upper (northern) part of the pit, where on the flat floor there was a cigar-shaped kiln for firing small fine vessels and small vessels with painted decoration (Minichreiter 1992c.42). The even southern surface of the working pit had a domed kiln with a horseshoe shaped foundation, which probably also served for firing clay objects. This kiln was badly damaged, and its form could not be reconstructed with certainty. The western part of the working pit contained two smaller pits (dug to a depth of $50 \mathrm{~cm}$ ), on whose edges the potters could sit and control the vents and fuel during the firing period, and vessels could be set aside on the flat surfaces around both kilns during the production process. Charcoal samples from the southern section of the working pit were dated by ${ }^{14} \mathrm{C}$ analysis to the period $5370-5040$ BC $(6260 \pm 130 \mathrm{BP})$.

One of the most attractive examples of a dwelling structure is pit-dwelling 10 at Zadubravlje (Fig. 7). It was built in the central part of the settlement, southeast of the entrance to the central enclosed area (Minichreiter 1992. 29-35). It was shaped like a quatrefoil with a fourth narrower side $(6 \times 8 \mathrm{~m}$, dug in from 0.20 to 1.00 $\mathrm{m})$, and was the largest structure in the settlement in terms of dimensions. Because of its size, it had both a main and secondary entrance. The main entrance was on the eastern side, with one step and a row of perpendicular pots $3 \mathrm{~m}$ in length, which held up the beam over the entrance (Fig. 8). The secondary entrance was in the southwestern part of the structure, in fact a passage from the structure into a large courtyard (11 x $8 \mathrm{~m})$, which was enclosed by a wooden fence. The northern part of the fence was straight in plan, while the southern part of the fence was semicircular, with an entrance from the settlement on the southeastern side. The courtyard was used for producing fabric (a find of 37 clay weights from a vertical loom) and for crushing grain and other foods (20 fragments of stone querns). On the northwestern side of pit-dwelling 10 , a row extended of 6 regularly arranged vertical wooden beams (postholes $25 \mathrm{~cm}$ in diameter), which were placed parallel to the northern fence of the courtyard. These wooden beams probably supported a slanted roof - an overhanging eave, the southern side of which leant on the courtyard fence. The open

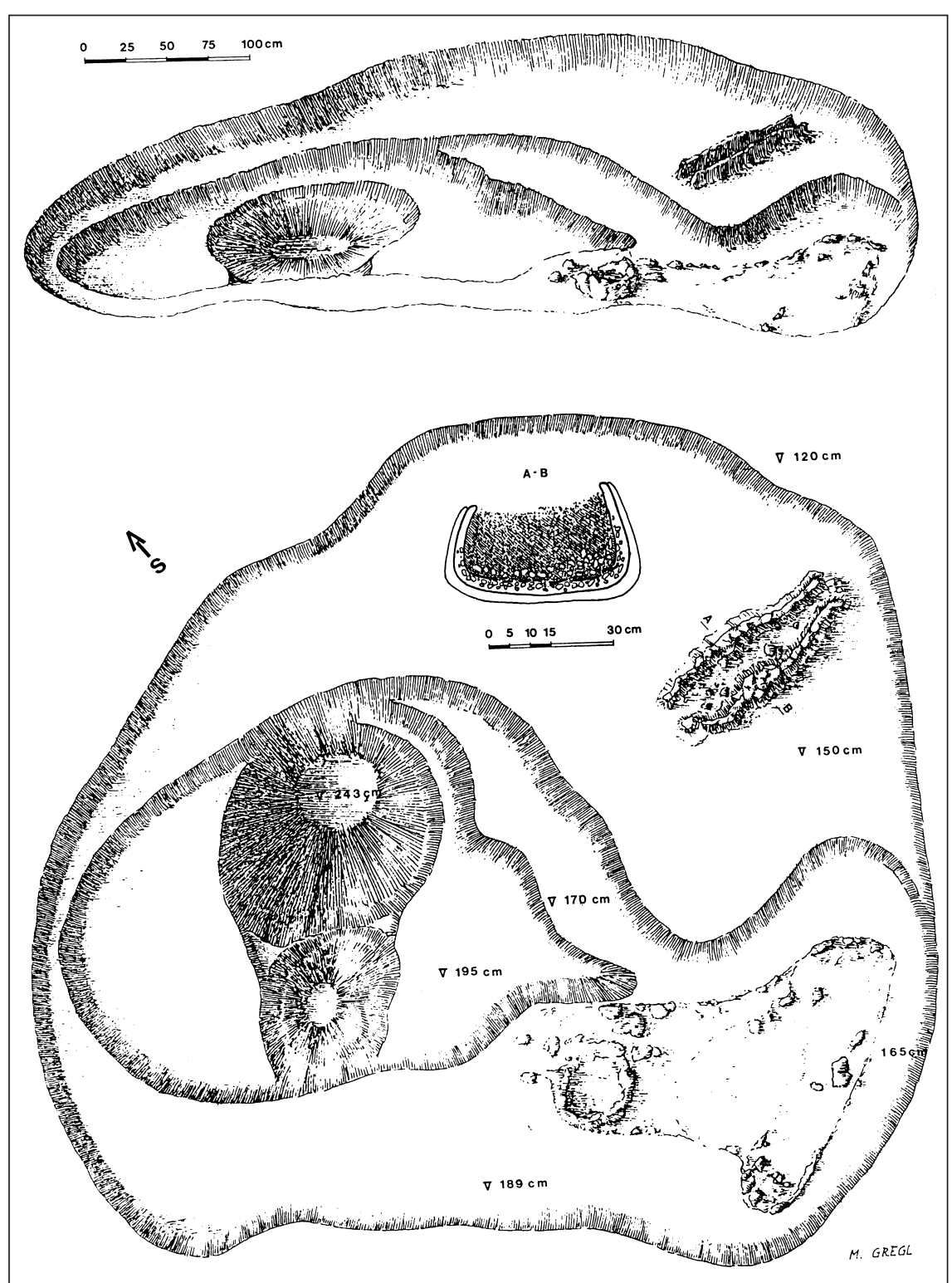

Fig. 6. Zadubravlje, working pit 12, pottery workshop with kilns, plan and perspektive (drawing: Miljenko Gregl). 
side of the 'eave-arcade' 10oked to the north, into the central, circular fenced area. Food for animals could have been kept, or everyday tasks could have been performed under this eave. The interior of pit-dwelling 10 (Fig. 8) was divided into 4 rooms: eastern, southern, western, and northern, the eastern (the first beyond the main entrance) being the largest, measuring $6 \mathrm{x}$ $4 \mathrm{~m}$. Numerous pottery frag-

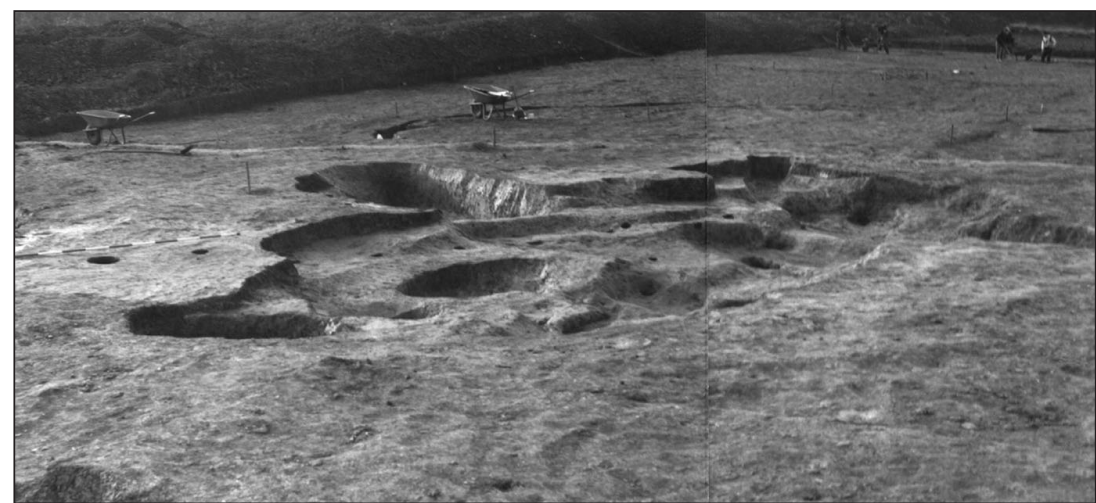

Fig. 7. Zadubravlje, residential pit-dwelling 10, during archaeological excavations (photo: $K$. Minichreiter). ments and pieces of bone were found in this room, and cult objects were prominent (Minichreiter 1992a. 7-10), which is logical, given its size and the possibility of gathering a large number of the inhabitants inside. A narrow pit was found between the eastern and western rooms (an identical area in pit-dwelling 6), which contained traces of densely arranged vertical posts, supported at the base with packed clay extending to a height of $45 \mathrm{~cm}$. The purpose of these structures remain merely conjecture, that is, that this could have been a household shrine. Pits of identical shape in plan, empty or with animal sacrifices, were found in Neolithic settlements at Branč (Vladar-Lichardus 1968.273-283) and at Endröd (Makkay 1992.131-132, Pl. 37/1,2; 39/1-4; 40/1-4), but those at Zadubravlje are the oldest among them according to the chronological sequence. Pits of similar form have been found at Starčevo settlements in Croatia at Pepelana (Minichreiter 1990.18), Černička Šagovina (Minichreiter 1992. 12), Vinkovci "Tržnica" (Dimitrijević 1966.39-42), and Kneževi Vinogradi, in Baranja (Šimić 1989.40), but we still lack sufficient elements for a definite evaluation of their purpose. Complete pots and the remains of animal bones were found in the western room, and a cattle horn was found buried in the floor below them. A similar example was found in the center of a large pit-dwelling with human burial at Slavonski Brod (Minichreiter 1999.12), and at the Obre I site in Bosnia and Herzegovina, where the bones of cattle and sheep were found under house $\mathrm{K}-1$, which were suggested by A. Benac to have been the remains of animal sacrifices made during the construction of this dwelling structure (Benac 1973. 16). An analysis of a charcoal sample using the ${ }^{14} \mathrm{C}$ method has dated the southeastern part of the pitdwelling to $5990-5740 \mathrm{BC}(6995 \pm 115 \mathrm{BP})$.

- The third type of structures were large pit-dwellings used both for habitation and ritual-burial pur- poses $(15 \times 7 \mathrm{~m}, 12.5 \times 6.5 \mathrm{~m}$, and $11 \times 4 \mathrm{~m})$ discovered at Vinkovci, Pepelana, and Slavonski Brod. At the Starčevo settlement at Pepelana, at site IIA (Minichreiter 1990.18), part of a large multi-roomed pit-dwelling was excavated to a length of $25 \mathrm{~m}$ and a width of $10 \mathrm{~m}$ (Fig. 17). The pit-dwelling could not be excavated entirely (because of the limited possibilities of excavating along the gas-pipeline), so the actual dimensions could not be established. The pit-dwelling was in the shape of a cross or inverted letter "T", with a wide southern and central area, and eastern, northern and western arms. A passageway, $5 \mathrm{~m}$ in length and $1.5 \mathrm{~m}$ in width, was formed in the eastern part of the central area. The passageway connected the southern, lower part of the pit-dwelling like a ground-floor level to the northern higher section of the "first floor" (with a height difference of around $1 \mathrm{~m}$ because of the inclination of the land). The eastern arm of the pitdwelling was entered from the central part of the passageway over one step, while three steps at the end of the passageway (Fig. 7) led to the northern arm, which again, via a platform in the central section, was connected to the western arm of the pitdwelling. The exterior edge of the large pit-dwelling was straight, while the edges of the smaller rooms had a step-like form ("bench"). Refuse pits were not found in the central section and its arms, while part of pit 10 (Fig. 15) in the southern section most probably served this purpose. In the "ground floor" of the pit-dwelling, its southern area, a large hearth was uncovered, with a circular plan, $1.5 \mathrm{~m}$ in diameter, and $30 \mathrm{~cm}$ thick, formed in a special niche along the eastern edge of the pit-dwelling. Very poorly preserved remains of human bones, i.e. the lower part of a leg in a contracted position, were discovered in a small niche opposite the hearth. In several places in the northern and central parts of the pitdwelling (the "first floor"), postholes of perpendicular wooden beams were discovered which held up 
the over-ground roof structure. The western arm of the large pit-dwelling contained an elongated narrow pit $(3.1 \mathrm{~m}$ in length, $25 \mathrm{~cm}$ in width, and $20 \mathrm{~cm}$ in depth), with no pottery finds. An identical pit was discovered west of this, but its purpose remains unknown.

An elongated pit-dwelling with several rooms (12.5 $\mathrm{x} 6.5 \mathrm{~m}$ ) was discovered in the northern zone of excavation at the Starčevo settlement at the "NAMA" site in Vinkovci (Dimitrijevic 1979.240).

Two large pit-dwellings ( $15 \mathrm{~m}$ in length, 7 and $5 \mathrm{~m}$ in width, dug to a depth of $1 \mathrm{~m}$ ) were discovered at Slavonski Brod during excavations of the Starčevo

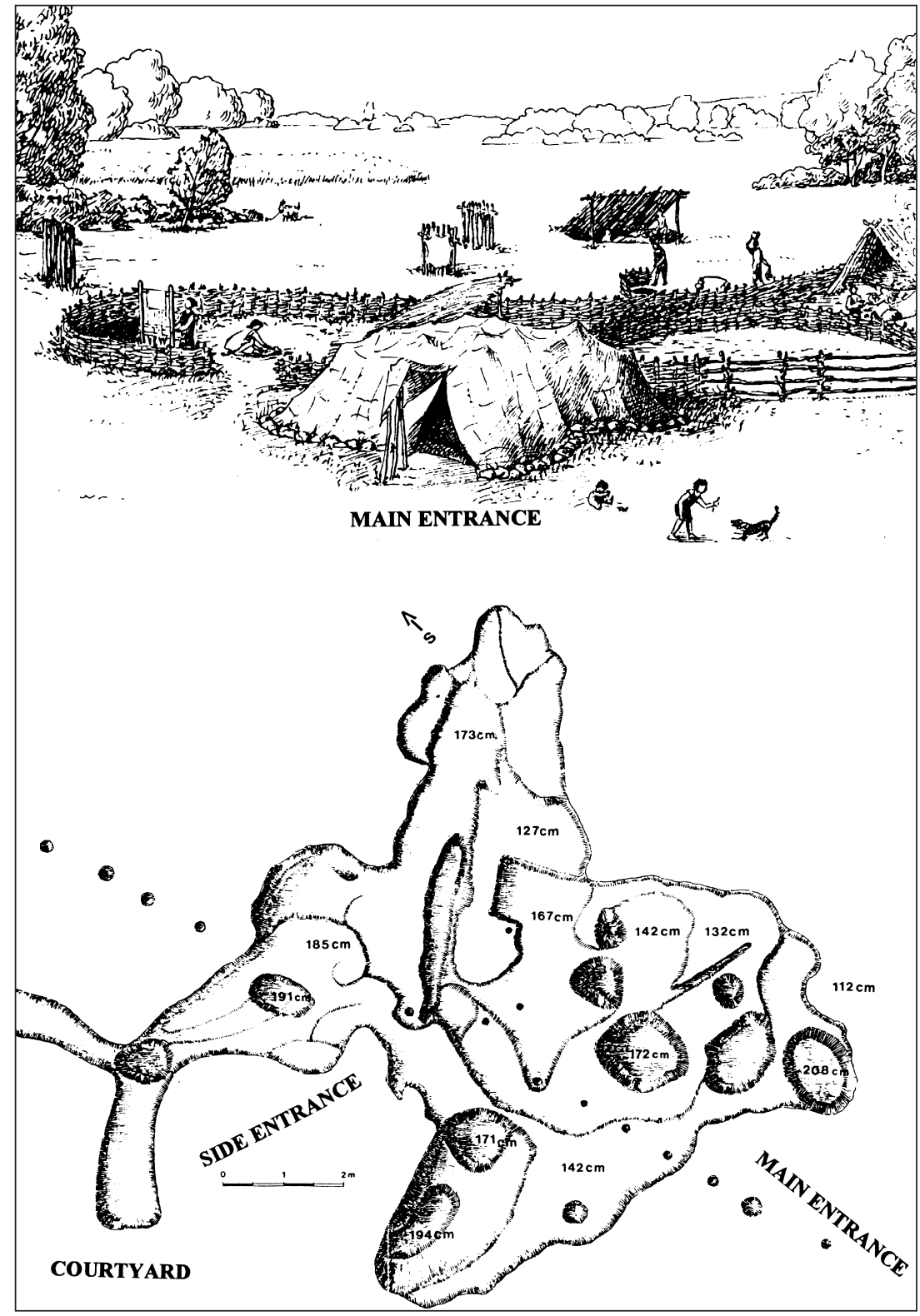

Fig. 8. Zadubravlje, residential pit-dwelling 10 with fenced courtyard, plan and perspective (drawing: Miljenko Gregl). settlement, one of which was for habitation within the settlement, and the other with human burials in a separate and enclosed ritual-burial area (Minichreiter 1998; 1999; 2000). The pit-dwelling was damaged on the northeastern side by uncontrolled excavation on the part of a brickworks (by extracting soil from this land to make bricks), so it is only hypothesized that the pit-dwelling had an entrance section on the eastern side. The pit-dwelling contained rows of postholes from perpendicular wooden beams and posts that supported the roof construction (Fig. 11). The usual household belongings were found within the pit-dwelling: numerous pottery vessels, parts of querns, stone tools, and the remains of animal bones. To the south, alongside the large pitdwelling, two small refuse pits ( $2 \mathrm{~m}$ in diameter) had been dug.

Another large pit structure, which was similar in form and dimensions to the pitdwelling, was discovered at the same site within the separated and enclosed ritual-burial area (Fig. 12). The entrance to the large pit-dwelling was via two steps on the eastern side into the central section. Two "cigar" shaped ovens were discovered in the northern room along the outside edge, and it is hypothesized that they served only for ritual purposes (no remains of pottery vessels were found in them as at Zabubravlje, where the kilns, additionally, had fuel sources from a semisubterraneous structure). Between these two sources, in the inner part of the pit-dwelling, the remains of two human skeletons in a contracted position were discovered (one missing the skull). The central part of the pit-dwelling (the geometrical center of the structure), not far from the entrance stairs, contained a group of pottery vessels, fragments of animal bones, and stone tools, including pieces of burnt earth with a smooth 

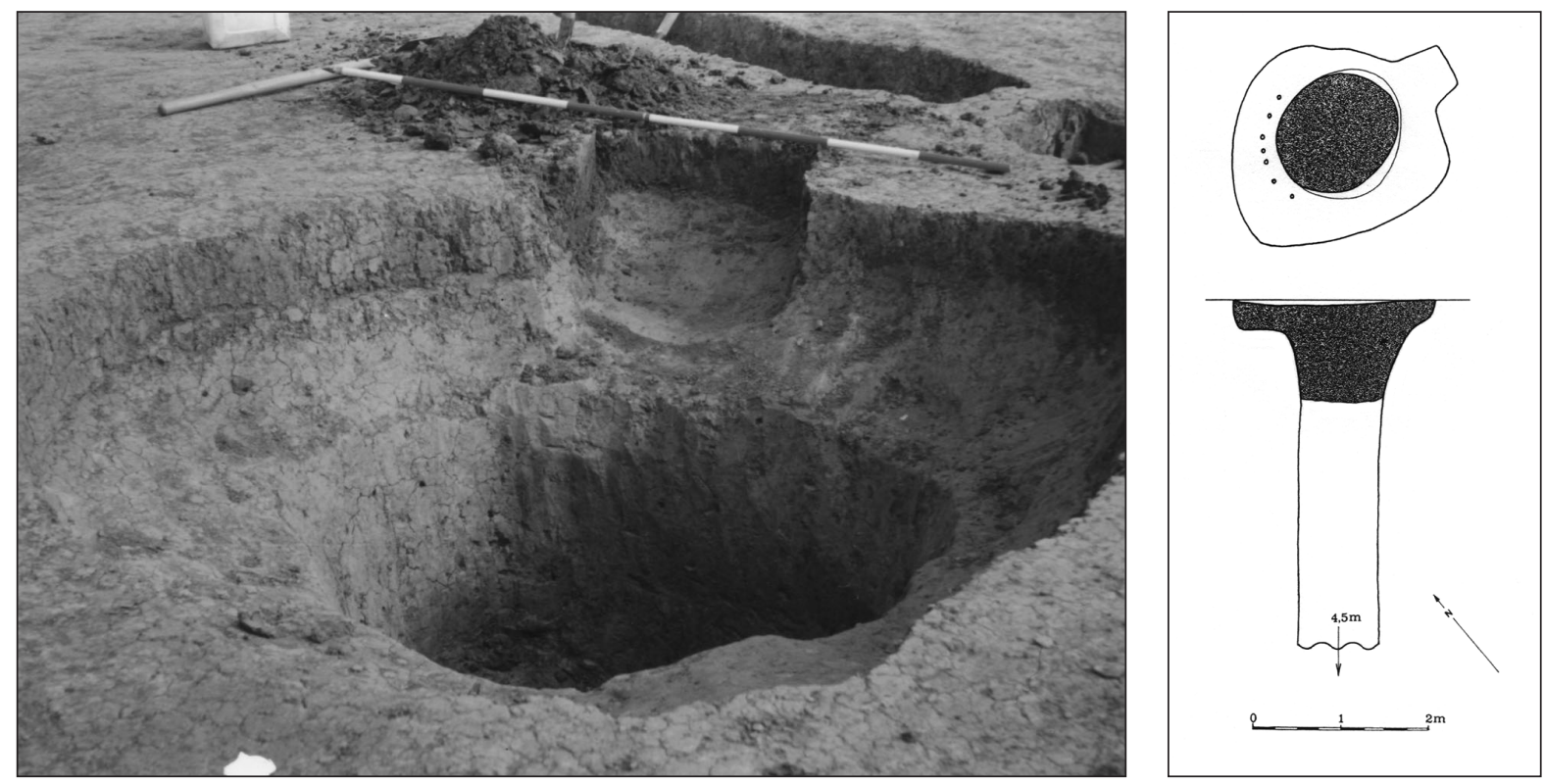

Fig. 9. Zadubravlje, the well during the excavations (photo: K. Minichreiter).

surface on one side, considered to have been parts of "altar tables". Below all this, a large cattle horn (Fig. 13) was buried in a cult manner in the subsoil, for which analogies exist at Zadubravlje in pit-dwelling 10 (Minichreiter 1992b.19), and Obre in Bosnia (Benac 1973.16). The southern section of the pit-dwelling contained three groups (each group contained pottery vessels, stone tools, and animal bones), which were arranged in equally spaced intervals. Between them were buried the remains of headless human skeletons, on whose northern side were placed a miniature altar in the form of an animal with a pack on its back and a lump of ocher ( $M i$ nichreiter 1998). This large pit structure did not have the usual roof construction of a pit-dwelling, as postholes were not found from vertical beams. It is hypothesized that only those sections of pit structure with buried human skeletons were covered with horizontally placed wooden logs. The northern and southern sections of the pit structure had edges shaped like a giant step ("bench"), where horizontal or slightly angled wooden logs could be rested. The central part of the pit structure could have been uncovered, as the inhabitants were probably present in this structure only under certain circumstances during special ceremonies, or while offering sacrifices in honor of the deceased who had been buried here. A charcoal sample from the northern part of the pit structure was dated by ${ }^{14} \mathrm{C}$ analysis to $5810-$ $5620 \mathrm{BC}(6835 \pm 110 \mathrm{BP})$.

- The fourth type of structure in settlements was deep pits - wells - discovered in the Starčevo settlement at Zadubravlje (Minichreiter 1992.35; 1993.
101-102; 1998a.25-31). A well was discovered in the western part of the settlement, west of the wooden fence connecting northern working pit no. 9 and southern dwelling pit no. 10, and which protected the central part of the settlement on the western side. The well in its uppermost section had a widened plateau $(2.5 \mathrm{~m}$ in diameter), with thin posts lined up as a protective fence on the western side, which is logical, as only from this side could people or animals fall into the well. No enclosure was necessary on the eastern side, as the main central area of the settlement, fenced off in a large circle, was not far from the well. In the eastern part of the well plateau, a dug out step was found, on which a thick wooden beam was probably placed to aid in drawing water (Fig. 9). The southern side of the platform had a small access plateau, and only from this side could one stand next to the well. The well had a diameter of $1.5 \mathrm{~m}$, and at a depth of 4.9 meter water appeared during investigations. The well was probably even deeper when it was in use. Several pottery fragments and stone tools were found inside, the finest find being a jug with four lugs and a high cylindrical neck, used for drawing water. Charcoal samples from the bottom of the well have been $\mathrm{da}$ ted by ${ }^{14} \mathrm{C}$ analysis to $6610-6340 \mathrm{BC}(7620 \pm 140 \mathrm{BP})$.

\section{URBANISM: THE ARRANGEMENT AND PURPOSE OF PIT STRUCTURES IN STARČEVO SETTLE- MENT STRUCTURES}

Archaeological excavations undertaken during the last 30 years in northern Croatia have led to new 
knowledge about the "urbanism" (the arrangement and purpose of pit structures) of the earliest Neolithic settlements in southern Pannonia through all the developmental phases of the Starčevo Culture.

\section{Zadubravlje: "The Craft Settle- ment" - The Linear A Phase (Fig. 10)}

An early Neolithic "craft settlement" of one tribal community was discovered at Zadubravlje during 19891990 , with an excavated surface area of $6200 \mathrm{~m}^{2}$ (Minichreiter 1992; 1992b; 1992c; 1993; 1997a). Certain sections of the settlement had strictly determined purposes: an area

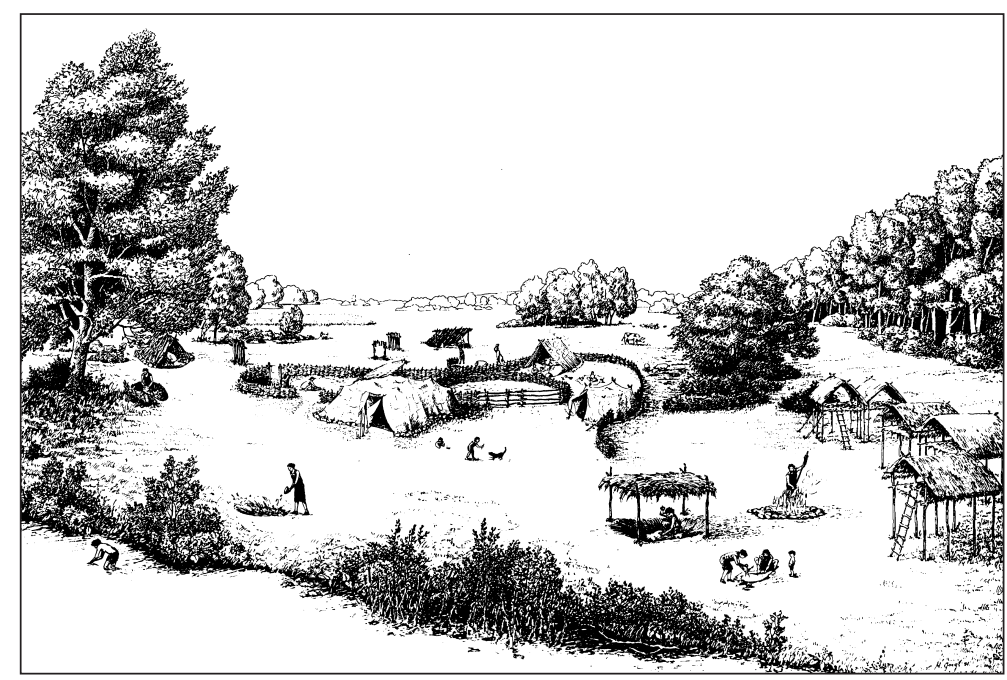

Fig. 10. Zadubravlje, the probable appearance of settlement of Early Starčevo Culture reconstructed on the basis of finds from Zadubravlje by K. Minichreiter (drawing: Miljenko Gregl). for storing and preparing food, a workshop for producing stone tools, cult and dwelling areas, courtyards for weaving fabric and grinding grain, pottery workshops with pits for extracting clay, and kilns for firing small and large pottery vessels and clay objects (Fig. 5, 6).

In the easternmost part of the settlement, postholes were uncovered of perpendicular beams probably used to support an above ground storage area for food, with a large open hearth next to it, where food was prepared for the population of the entire settlement (hearths were not found in the pit-dwellings, making this the only hearth in the settlement). Further towards the center of the settlement was a group of working pits: workshops for the production

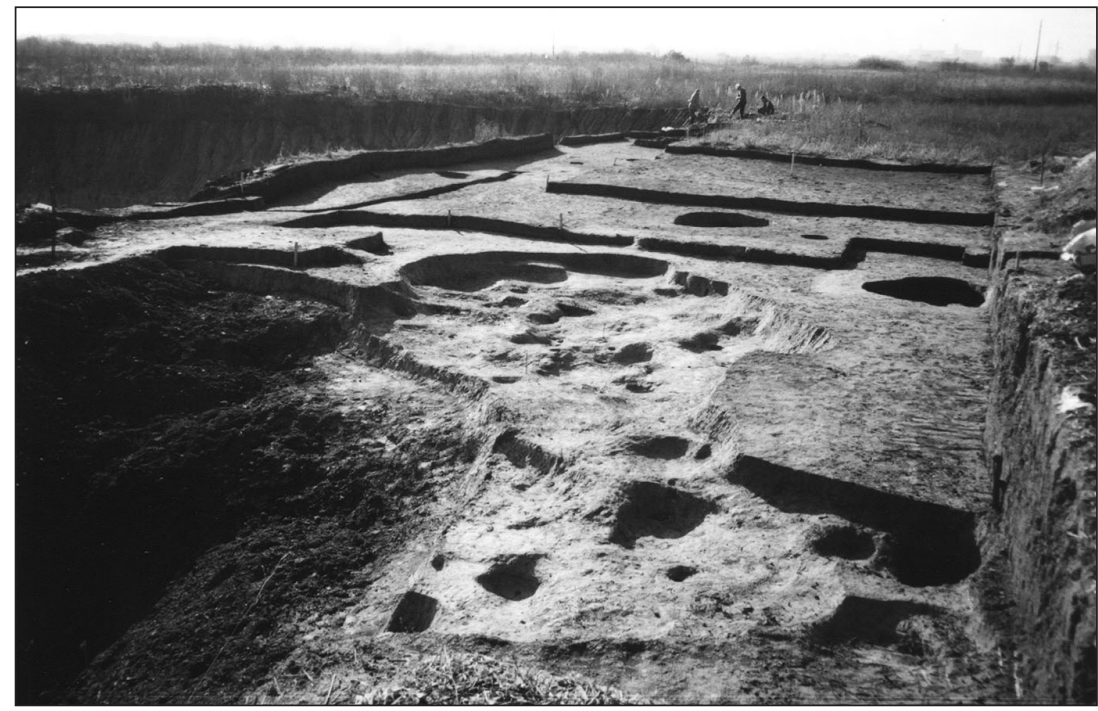

Fig. 11. Slavonski Brod, residential pit-dwelling of the Starčevo setllement (photo: K. Minichreiter). of stone tools and weapons. The central area of the settlement contained two pit-dwellings (northern no. 6 and southern no. 10) with sacrificial pits, with a circular enclosed area of unknown purpose between them. It probably served as a gathering point for the population during certain rites, or perhaps was used for penning stock. The southern pit-dwelling had a semicircular, enclosed courtyard where fabric was produced (weights from a vertical loom were found along the southern fence, where the loom was probably supported), and numerous remains of stone querns indicate the grinding of grain and other foodstuffs and food preparation for the entire community. The central area of the settlement was protected on the western side from animal intrusion by a wooden fence, which also connected the northwestern working pit with the kilns and ovens and the southern pit-dwelling. Beyond the fence, on the western side, a well was dug (depth ca. $5 \mathrm{~m}$ ), with a system for extracting water (a horizontally placed wooden $\log$ ), and a small protective fence on the western side. The western part of the settlement contained pottery workshops with kilns (working pits no. 9, 12, 14) and working pits for the extraction and treatment of clay (pits 32, 33, 34, 35). Working pit 9 contained a double kiln (cylindrical) for firing large 


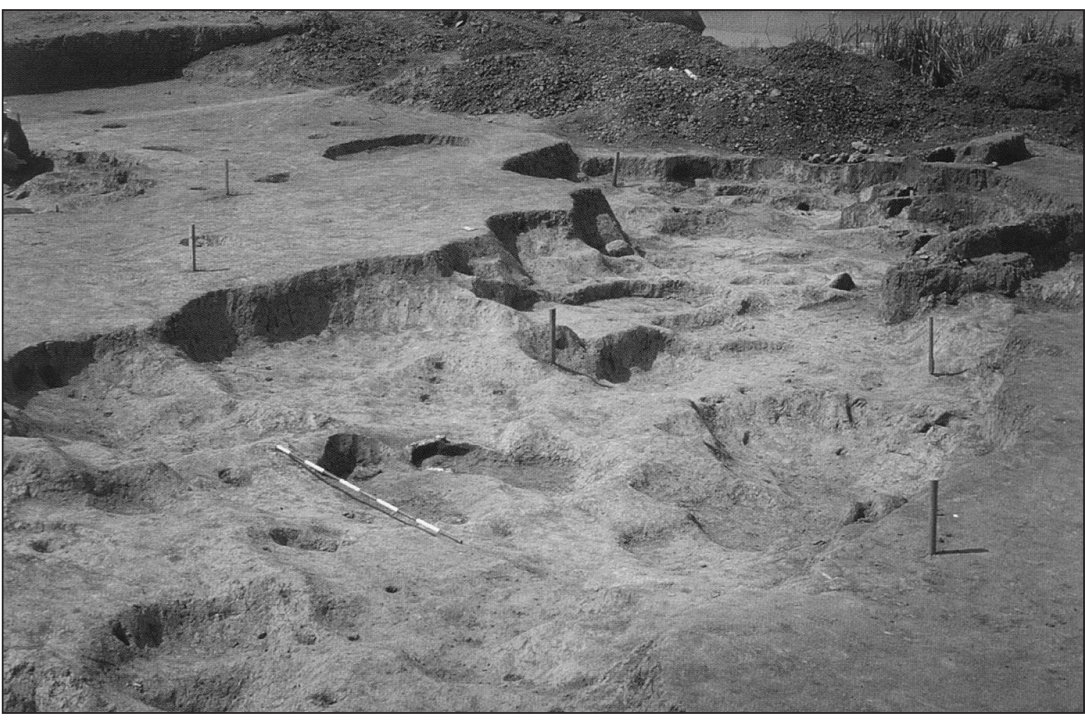

Fig. 12. Slavonski Brod, pit-dwelling in the Starčevo ceremonial and burial area site (photo: $K$. Minichreiter).

vessels, and two bread ovens (hemispherical forms). Working pit no. 12 contained two kilns: one quite damaged (horseshoe-shaped in plan), and another, of "cigar" shape, for firing fine and painted pottery. Working pit no. 14 contained another "cigar" kiln, of somewhat greater dimensions than the kiln in pit 12. This part of the settlement also had pits for the extraction and working of clay, as semicircular wooden fences were found next to the pits that contained packed clay used in the preparations for making pottery vessels. On the basis of material found during excavations, a reconstruction (on paper) was carried out for the first time in this part of Europe of an early Neolithic "craft" settlement of the Starčevo Culture, as discovered in northern Croatia.

\section{Slavonski Brod: The Settle- ment and the Ritual-Burial Area - The Linear A Phase}

From 1997, systematic archaeological excavation was undertaken in Slavonski Brod at a large settlement of the Starčevo Culture, where a specially separated ritual-burial area was discovered with the buried remains of selected members of this tribal community (Minichreiter 1998; 1999; 2000). A surface area of $1500 \mathrm{~m}^{2}$ has been excavated, and excavations still continue. A cult-burial area was separated and enclosed by a semicircular wooden fence, in which one large and one small pit were found (Fig. 14). The large pit-dwelling (15 x $7 \mathrm{~m})$ had an entrance on the eastern side, and a clump of pottery in its center, beneath which a cattle horn had been ceremonially buried. The northern part of the pit-dwelling contained two "cigar" shaped kilns, which had fuel sources on the exterior side of the pit structure, and which probably served only for ritual purposes. Two human skeletons (one headless) were buried near the kilns in the pit-dwelling, in a contracted position, covered with soil mixed with pieces of pottery and stone tools. Three groups of pottery vessels were discovered in the southern section of the pit-dwelling (special rites probably took place here in honor of the deceased), as well as one human burial, in a contracted position, and lacking a head. The pit-dwelling did not have a large roof construction, and it was probably only partly covered by a low cover of horizontally placed wooden logs. To the west of the large pit-dwelling, a small pit-dwelling was discovered $(5 \times 5 \mathrm{~m}$, dug to a depth of $1 \mathrm{~m}$ ), with an entrance stair on the northern side. To the east of the entrance, a large group stone axes and minor tools was discovered, while in the western section, human skeletons having only the rear portion of the skull buried in a contracted position.

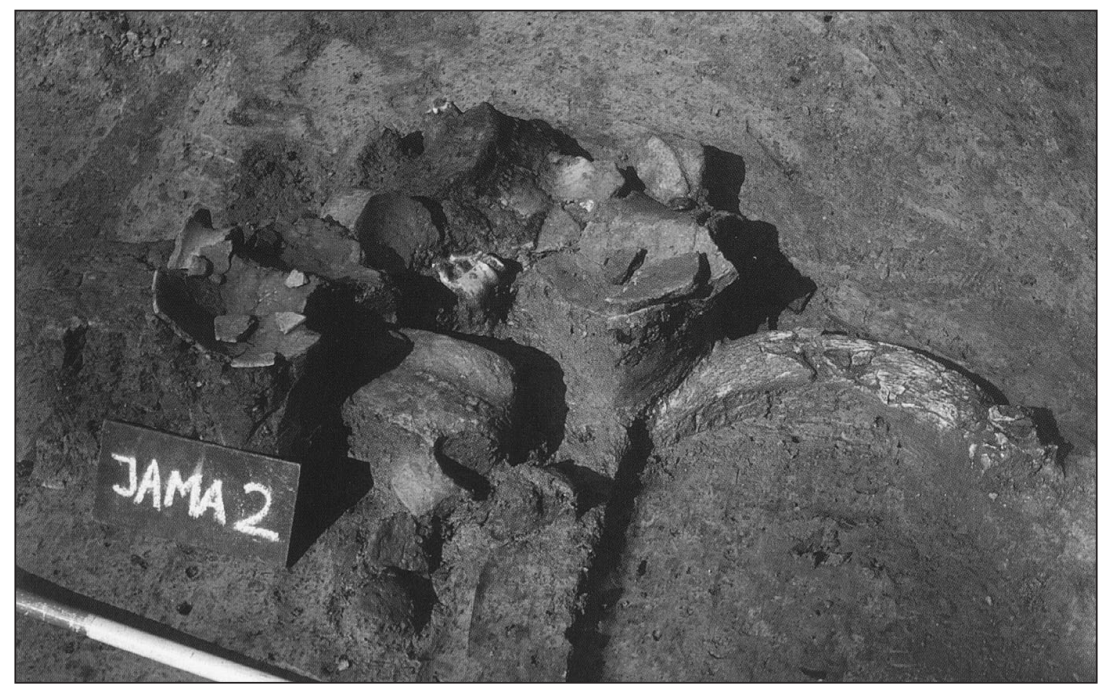

Fig. 13. Slavonski Brod, a group of ceramic pottery above the cattle horn in the middle of the pit-dwelling in the Starčevo ceremonial and burial area site (photo: $K$. Minichreiter). 
The skeleton was buried under soil mixed with pottery fragments, tiny stone tools, clay discs, and parts of zoomorphic religious sculptures (duck heads). Postholes from small poles were found on the edges of the pit-dwelling, and around the pit-dwelling there were holes of perpendicular wooden beams (30-40 cm in diameter) arranged in rows, so that a wide arcade existed above the entrance section of the dwelling, indicating the special formal character of this pit-dwelling, where, probably, a prominent member of the tribal community was buried. On the northwestern side, the ritual-burial area was enclosed by a semicircular wooden fence, and on the southwestern side by a free-standing double semicircular fence, whose purpose is not entirely clear at present. The western section contained rows of postholes from large wooden columns that could have held up an eave above the "western gates" - the passage from the settlement into the ritual-burial area. Beyond the fence and further to the west, the settlement continued, where to date two pit-dwellings and several refuse pits in their vicinity have been excavated. One pit-dwelling was large (15 x 5 $\mathrm{m})$, in form, size, and orientation very similar to the one in the ritual-burial area, except this pit-dwelling had rows of postholes from wooden beams that supported a roof above it. The entrance to this pit-dwelling was most probably on the eastern side, but this could not be confirmed, as this part of the structure was destroyed by extraction for the brickworks. Archaeological excavations will continue at this site, which will enable an overview of the arrangement of structures at what is so far the largest settlement from the early phases of development of the Starčevo Culture not merely in Croatia, but also in the broader region of southern Pannonia.

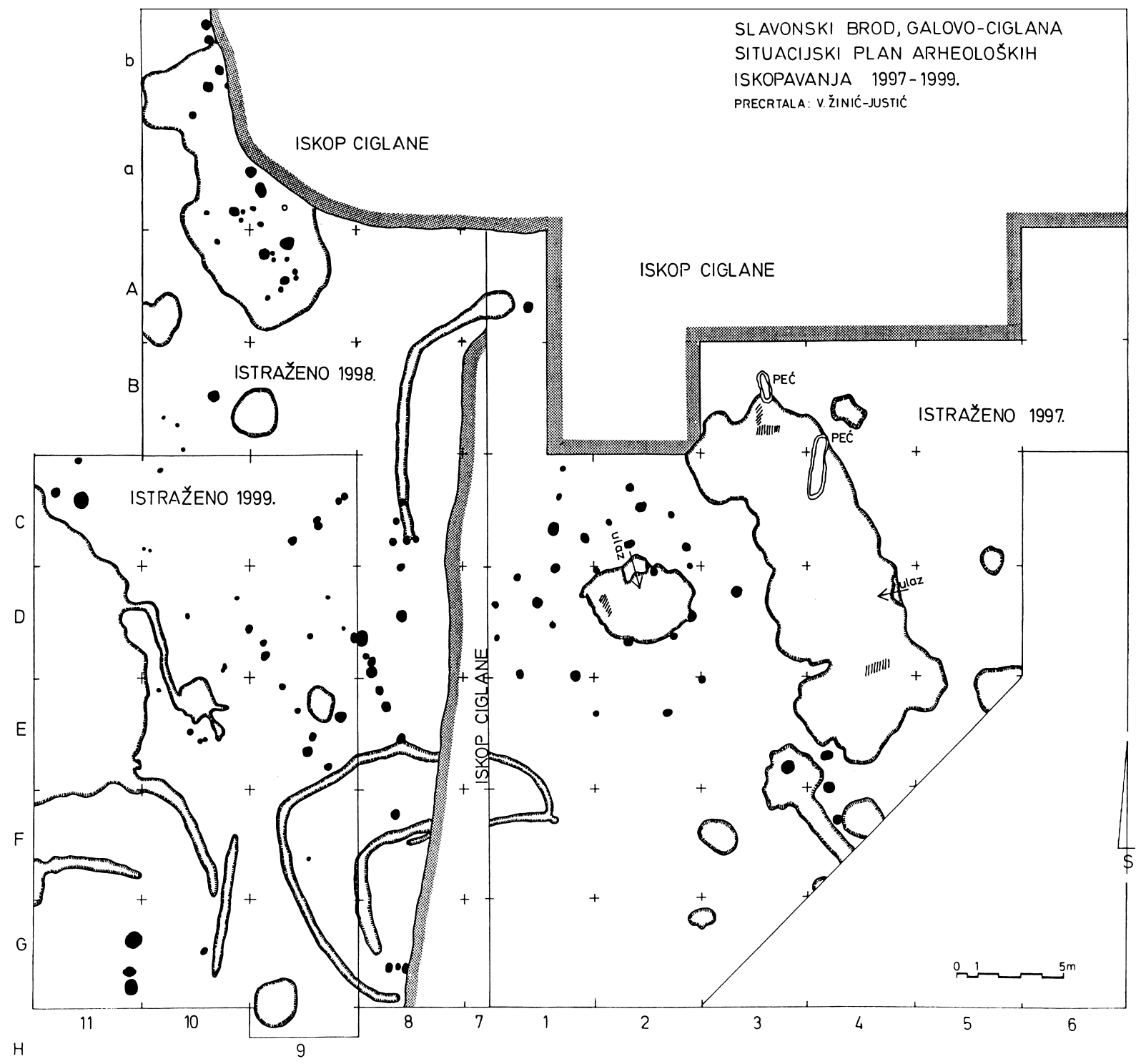

Fig. 14. Slavonski Brod, the situational scheme of archaeological field research in 1997, 1998 and 1999. 


\section{Pepelana: The Neolithic and Eneolithic Settlement - The Linear C Phase}

A rescue excavation was carried out in 1985 on the route of the gas pipeline from Pepelana to Suhopolje, where a surface area of $400 \mathrm{~m}^{2}$ was investigated to an average depth of $1 \mathrm{~m}$. The site extends over an area of $800 \times 1000 \mathrm{~m}$. The archaeological complex is composed of a large tell, $90 \mathrm{x}$ $90 \mathrm{~m}$, by $4 \mathrm{~m}$ in height, and two elongated hills that gently descend to the banks of the Brežnica River (Minichreiter 1992.17-20). As the extent of the excavation was limited, only one large pit-dwelling on a hill was investigated, with a length of $25 \mathrm{~m}$ and width of $10 \mathrm{~m}$ (Fig. 17). The pit-dwelling was shaped like a reversed letter "T" with a wide southern and central area, and eastern, northern, and western arms. The eastern section of the central area contained a passageway $5 \mathrm{~m}$ long and $1.5 \mathrm{~m}$ wide that connected the southern, lower part of the "ground floor" of the pitdwelling, and the upper "first floor". From the central part of the passageway, one step led to the eastern arm of the pit-dwelling, while across three steps the northern arm was reached, which was connected to the western arm of the pit-dwelling across a platform in the central section. The southern section of the pit-dwelling had a deeper dug pit for refuse, which contained discarded pottery fragments. A large hearth was also discovered in the southern area, $1.5 \mathrm{~m}$ in diameter and $30 \mathrm{~cm}$ thick, and opposite this, the remains of a human skeleton in a contracted position were buried. The northern and central part of the pit-dwelling contained postholes from large perpendicular columns that held up the above-ground roof construction. Two small working pits were discovered northeast of the pit-dwelling. The relatively limited area excavated at Pepelana meant that the arrangement of the structures in the settlement could not be determined, but the excavated pit-dwelling showed a previously unknown form of construction on two levels ("ground floor and first floor").

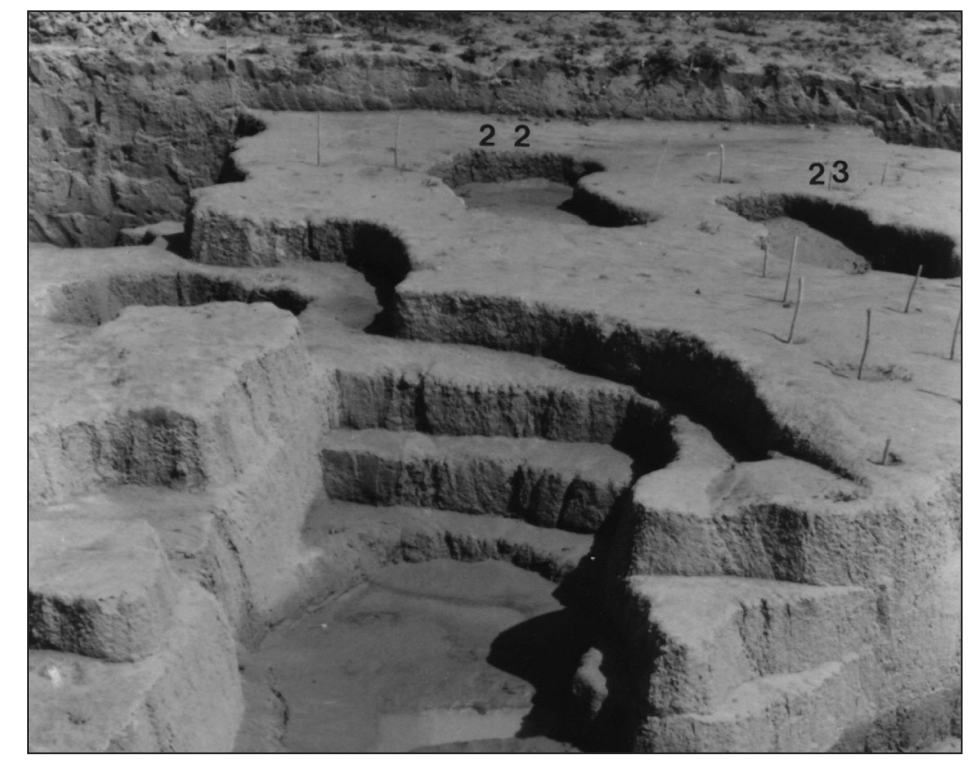

Fig. 16. Pepelana, working pit 22 and 23 (photo: K. Minichreiter).

\section{Vinkovci: a multi-strata settlement of the Star- čevo Culture - Linear B to Spiraloid B Phase (Fig. 18)}

In the southern part of the town of Vinkovci, on the elevated bank of the Bosut River, a multi-strata settlement from the late developmental phases of the Starčevo Culture was found at several scattered sites in rescue excavations (Dimitrijević 1979.238-240; Iskra-Janošič 1984.143-151; Minichreiter 1992.2428). At the "Tržnice" (Market) site, a micro-unit of the Starčevo settlement was found, and this in the northern and southern zones, while the empty central area contained only several fragments of pot- 
tery. Subterranean dwellings with several rooms were discovered in the southern zone of "Tržnice". One of the pit-dwellings had a trefoil shape, and another trapezoidal. The pit-dwellings had an entranceway, and on its edges on the exterior and interior sides, postholes were found from the wooden beams that supported the roof. Along the steep sides of the pit-dwelling, support posts were inserted (oblique or horizontal), which strengthened the interior row of bearing beams. An oven of some type, with an arched covering, most probably a kiln used for firing pottery, was discovered north of

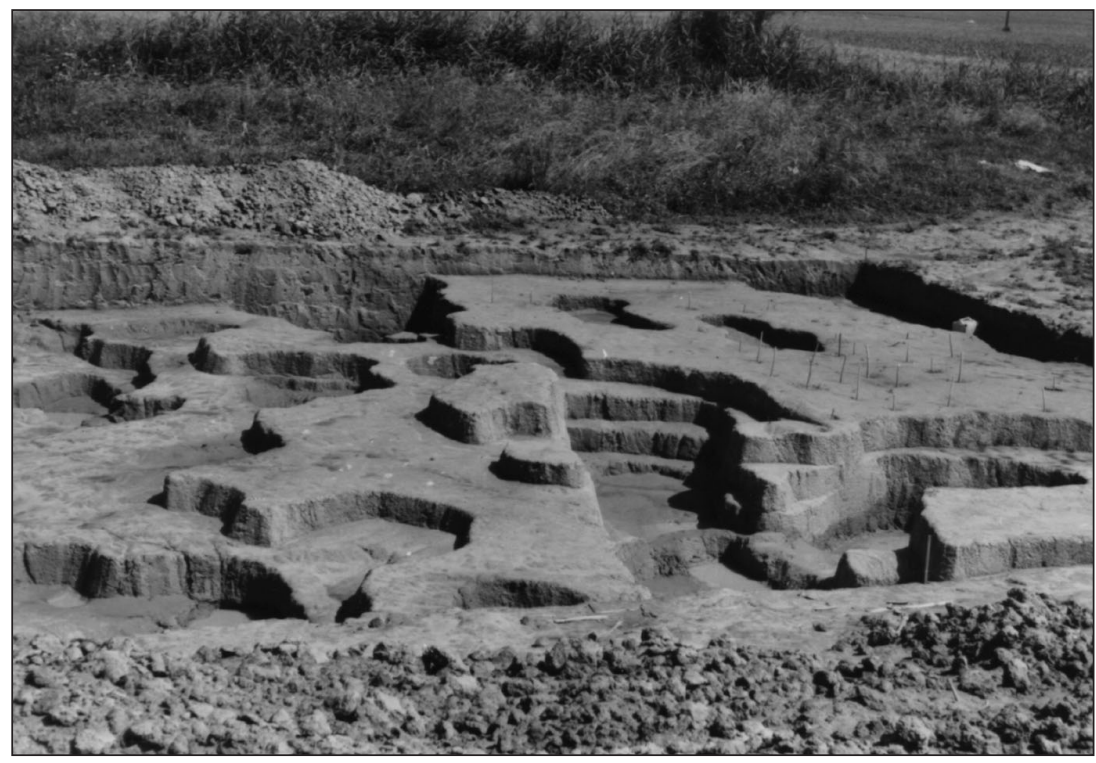

Fig. 17. Pepelana, residential pit-dwelling with a passage in upper level, the Classical phases - Linear C of the Starčevo Culture (photo: K. Minichreiter). the pit-dwelling. Shallow excavated pits, which were probably working areas, were discovered in the northern zone of the "Tržnice" site. At the site of "Cibalae Banka" (Jugobanka), part of the Starčevo settlement was discovered with densely dug, small working and refuse pits (Fig. 18), and two groups of structures were discovered at the "Nama" department store site. The northern zone contained two pit-dwellings of medium size $(12.5 \times 6.5$ and $9.7 \times$ 5.5 ), and seven smaller pits (probably for refuse) that surrounded it in a horseshoe shape. One of

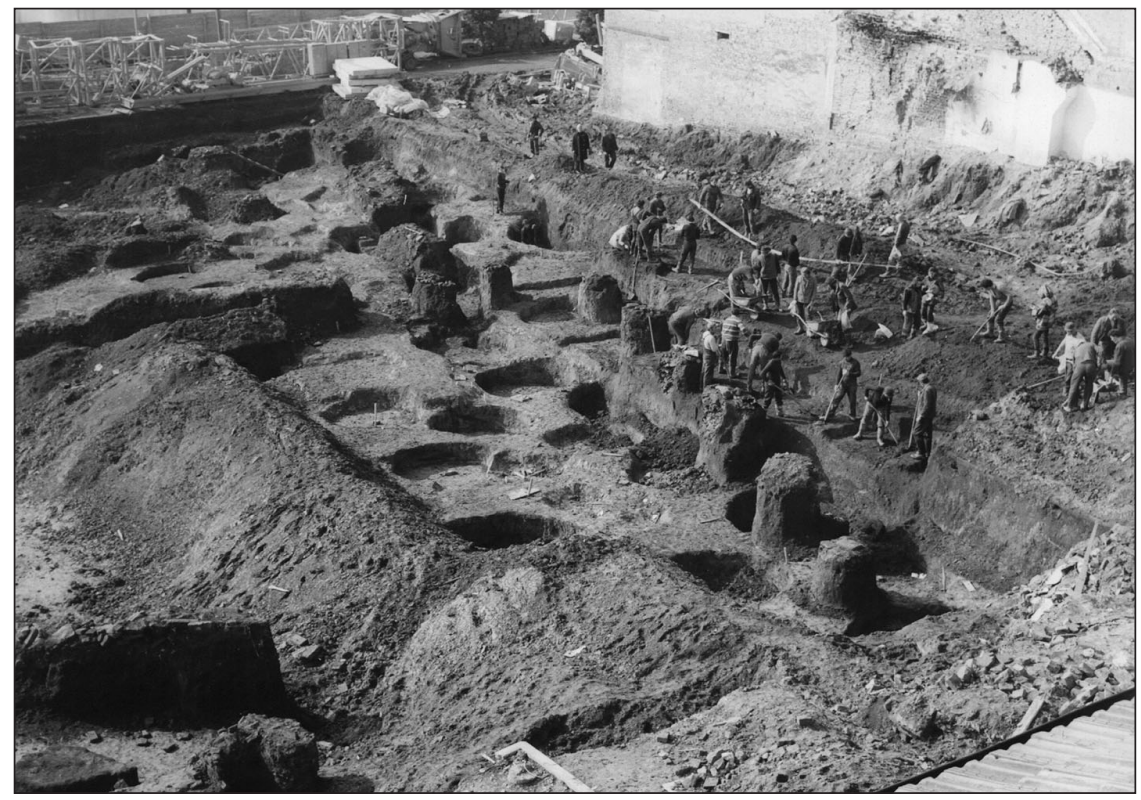

Fig. 18. Vinkovci, Cibalae banka (Jugobanka), Starčevo horizon of production and refuse pits - the Classical phases Linear B and Spiral B (photo: $K$. Minichreiter). these pit-dwellings contained the buried remains of 7 human skeletons in a contracted position. Six pit structures were found in the southern part of the "Nama" site: one large pit-dwelling (11 x $4 \mathrm{~m})$ and three medium ones $(5 \times 4 \mathrm{~m}, 6 \times 4 \mathrm{~m}$, and $6 \times 4.5$ $\mathrm{m})$, and two small refuse pits. A grouping of dwelling structures with empty areas between them, was noted at all the Vinkovci sites.

The numerous archaeological excavations in the past 25 years in northern Croatia have enabled a review of the development of Starčevo Culture settlement (the earliest Neolithic culture in this region) from its beginnings to the final stage of its development. The results of research up to the present have enabled us to identify the basic elements of the "urban" growth of these settlements, and the arrangement, form, and purpose of the pit structures in them; this will serve as fundamental material for the further investigation of the very first cultures in these areas, and the process of the spread of the Neolithic throughout southern Europe. 


\section{REFERENCES}

ARANĐELOVIĆ-GARAŠANIN D. 1954. Starčevačka kultura, Ljubljana: 1-151

BENAC A. 1973. Obre I. Glasnik Zemaljskog muzeja Bosne i Hercegovine u Sarajevu n.s. vol. XXVII XXVIII.

DIMITRIJEVIĆ S. 1966. Rezultati arheoloških iskopavanja na području vinkovačkog muzeja od 1957. do 1965.g. 20 godina Muzeja Vinkovci: 35-99.

1969. Starčevačka kultura u slavonsko-srijemskom prostoru i problem prijelaza starijeg u srednji neolit u srpskom i hrvatskom Podunavlju, (Die Starčevo-kultur im Slawonisch-Syrmischen Raum und das Problem des übergangs vom Älteren zum Mittleren Neolithikum im Serbischen und Kroatischen Donaugebietet), Neolit i eneolit u Slavoniji: $1-96$.

1974. Problem stupnjevanja starčevačke kulture s posebnim obzirom na doprinos južnopanonskih nalazišta rješavanju ovog problema (Das Problem der Gliederung der Starčevo-kultur mit Besonderer Rücksicht auf den Beitrag der Südpannonischen Fundstellen zur Lösung dieses Problems). Počeci ranih zemljoradnickkih kultura u Vojvodini i srpskom Podunavlju, Materijali X: 59-121.

1978. Neolit u sjeverozapadnoj Hrvatskoj - Pregled stanja istraživanja do 1975. godine, (Das Neolithikum in Nordwestkroatien - Überblick über den Stand der Forschung bis 1975), Arheološka istraživanja u sjeverozapadnoj Hrvatskoj, Izdanje Hrvatskog arheološkog drustva, band 2: 71-128.

1979. Sjeverna zona. Praistorija jugoslavenskih zemalja II, Neolit: 229-362.

ISKRA-JANOŠIĆ I. 1984. Arheološka istraživanja na području općine Vinkovci (Archäologische Forschungen im Gebiet der Gemeinde Vinkovci), Arheološka istraživanja u istočnoj Slavoniji i Baranji, Izdanje Hrvatskog arheološkog društva band. 9: 143-151.

MAKKAY J. 1992. Excavations at the Körös culture settlement of Endröd - Oregszölög 119 in 19861989, Cultural and Landscape Changes in SouthEast Hungary I, Reports on the Gyomaendrod Projekt.
MILOJČIĆ V. 1950. Körös - Starčevo - Vinča, Reinecke Festschrift: 108-120.

MINICHREITER K. 1990. Starčevačko naselje u Pepelanama kod Virovitice (Eine Ansiedlung der Starčevo kultur in Pepelane bei Virovitica), Vjesnik Arheološkog muzeja u Zagrebu, 3 serija - vol. XXIII. $17-40$.

1992. Starčevačka kultura u sjevernoj Hrvatskoj (The Starčevo Culture in Northern Croatia): 1-104.

1992a. Kultni predmeti starčevačke kulture u sjevernoj Hrvatskoj (Kultgegenstände der Starčevokultur in Nordkroatien). Prilozi Instituta za arheologiju u Zagrebu, vol. 9/1992: 7-22.

1992b, Ranoneolitička arhitektura sjeverne Hrvatske (Frühneolithische Architectur Nordkroatiens). Porocilo o raziskovanju paleolita, neolita in eneolita $v$ Sloveniji XX: 17-25.

1992c. Peći u starčevačkom naselju kod Zadubravlja (Öfen in der Starčevo Kultur Stammenden Siedlung bei Zadubravlje), Opuscvla archaeologica vol. 16: 37-49.

1993. Arhitektura starčevačkog naselja kod Zadubravlja (The arhitecture of the Starčevo settlement at Zadubravlje near Slavonski Brod). Arheološka istraživanja u Slavonskom Brodu i Brodskom Posavlju, Izdanje Hrvatskog arheološkog drustva vol. 16/1991: 97-111.

1997. Otkriče u Lukaču i Požegi kao prilog poznavanju topografije naselja starčevačke kulture $\mathrm{u}$ sjevernoj Hrvatskoj (Entdeckung in Lukač und Požega als ein Beitrag zur Kenntnis der Topographie der Siedlungen der Starčevo-Kultur in Nordkroatien). Prilozi Instituta za arheologiju u Zagrebu, vol. 11-12/1994-1995: 7-36.

1997a. Otkriče najstarijeg bunara na tlu Hrvatske $\mathrm{u}$ arheološkim istraživanjima kod Slavonskog Broda (Discovery of the Oldest Well on the Territory of Croatia during Archaeological Investigations in the Area of Slavonski Brod). Hrvatske vode vol. 5, number 20: 215-221.

1998. Zoomorfna idoloplastika obredno-ukopnog prostora starčevačkog lokaliteta na Galovu u Sla- 
vonskom Brodu (Zoomorphic Idols on the Starčevo Ceremonial and Burial Area Site at Galovo, Slavonski Brod). Prilozi Instituta za arheologiju u Zagrebu, vol. 13-14/1996-1997: 7-22.

1998a. The Oldest Neolithic Water-Well in Croatia from the Early Starčevo Settlement near Slavonski Brod. Brunnen der Jungsteinzeit, Internationales Symposium in Erkelenz 27. bis 29. October 1997, Materialien zur Bodendenkmalpflege im Reinland 11: 25-31.

1999. Ranoneolitički ukopi i pogrebni običaji u naseljima starčevačkog kulturnog kompleksa (Early Neolithic Burials and Funerary Customs in Settlements of the Starčevo Culture Complex). Prilozi Instituta za arheologiju u Zagrebu, vol. 1516/1998-1999: 5-20.
2000. Reljefni prikaz ženskog lika na posudama starčevačke kulture (Relief Images of Female Figures on Starčevo Culture Vessels). Prilozi Instituta za arheologiju u Zagrebu, vol. 17/2000: 515.

SREJOVIĆ D. 1969. Naslednici (Les Heritiers). Lepenski Vir, nova praistorijska kultura u Podunavlju: $1-328$.

ŠIMIĆ J. 1989. Kneževi Vinogradi/Osnovna škola, Neolitsko naselje (Kneževi Vinogradi/Primary school, Neolithic Settlement). Arheološki pregled 28, Archaeological Reports 1987: 40.

VLADAR J., LICHARDUS J. 1968. Erforschung der Frühaneolithischen Siedlung in Branč. Slovenska Archeologia XVI-2. 